\title{
Evaluating the Delivery of Life Skills (LS) at the First Cycle of the Basic Education in the Sultanate of O man: Teachers' Perspectives
}

\author{
Tariq Y. Jawarneh* \\ Al Ain University of Science \& Technology, United Arab Emirates \& Yarmouk University, Jordan
}

Submitted: 20/2/2012

Revised: $2 / 10 / 2012$

Accepted: 3/10/2012

This study aims at evaluating the delivery of Life Skills (LS) at the first cycle of the basic education in Oman. Information was sought relative to teachers' perception of their abilities and confidence in implementing LS activities, the primary factors that affect teachers' initial involvement in LS, benefits of LS activities for children, how LS activities are being implemented, physical resources that teachers need in implementing LS activities, and barriers to the implementation of LS. The population of this study consisted of all teachers teaching at the first cycle of the basic stage of schooling in Oman ( $\mathrm{N}=2396)$. A multi-stage random sampling approach was used to select 315 teachers using the 2010/ 2011 Ministry of Education (MoE) directory. A questionnaire was adopted and modified to gather the required data. To analyze the data, means and standard deviations as well as frequencies and percentages were computed for responses to each item. The study revealed that teachers at the first cycle of the basic education stage possess several skills related to LS delivery. The results, however, revealed that teachers at the first cycle lack the necessary skills to adopt problem-solving approach in the implementation of LS activities, in addition to their incompetency to integrate information technology in LS related instruction. Several barriers to LS delivery were also identified.

Keywords: life skills, pre-vocational education, design and technology education, constructivism.

$$
\begin{aligned}
& \text { تقييم واقع تدريس المهارات الحياتية يخ مدارس الحلقة الأولى من التعليم الأساسي يِ سلطنة عمان كما يراها المعلمون } \\
& \text { * طارق يوسف جوارنه } \\
& \text { جامعة العين للعلوم والتكنولوجيا، الإمارات العربية المتحدة وجامعادة اليرموك، الأردن }
\end{aligned}
$$

هدفت هذه الدراسة إلى تقييم واقع تدريس المهارات الحياتية ِِّ مدارس الحلقة الأولى من التعليم الأساسي يخّ سلطنة عمان كها يراها معلمو التربية الابتدائية. وتركزت عملية جهع المعلومات على تصورات معلهي الحلقة الأولى يْ التعليم الأسـاسي

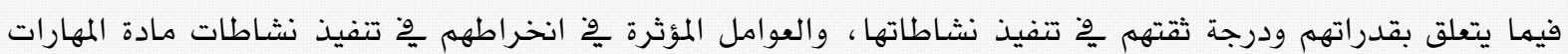
الحياتية، وفوائد المهارات الحياتية للأطفال، والكيفية التي تتفذ بها نشاطاتها، والمصادر المختلفة التي يحتاجها معلهو المرحلة الابتدائية لتتفيذ نشاطات المهارات الحياتية، ومعيقات تدريس المهارات الحياتية. تكون مجتهع الدراسة من جميع معلمي الحلقة الأولى من التعليم الأسـاسي يخ سلطنة عمان البالغ عددهم 2396 معلما ومعلمة. واستخدمت الطريقة الطبقية

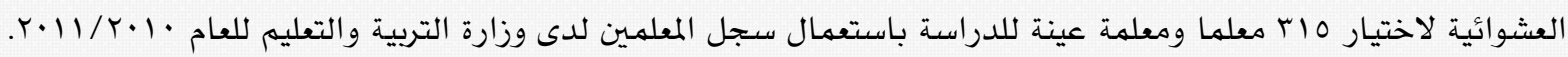
ولجهمع البيانات المطلوبة وظفت استبانة تم تبنيها وتطويرها لتتتاسب مع البيئة العهانية. ولتحليل بيانات الدراسـة ، استخرجت الأوساط الحسابية والانحرافات المعيارية والتكرارات والنسب المئوية لجميع فقرات الاستبانة. وقد أظهرت نتائج الدراسة امتلاك معلمي الحلقة الأولى ِوْ التعليم الأساسي للعديد من مهارات تطبيق مادة المهارات الحياتية، فيها أظهرت نتائج الدراسة ضعفا ِوْ امتلاك المعلمسين لمهارات اسلوب حل المشككلات، فضلا عن نقص الكفاءة لديهم فيما يتعلق بتوظيف تكنولوجيا المعلوهات والاتصالات وِّتفيذ نشاطات المهارات الحياتية.وكشفت الدراسة عن العديد من المعيقات التي تحول دون التنفيذ الفعال لنشاطات المهارات الحياتية.

الكلمات المفتاحية : مهارات حياتية، تربية مهنية، التصميم والتكنولوجيا ، النظرية البنائية.

* jawarneh786@gmail.com 
Like many countries, Oman has been involved in several school reforms. Education has undergone significant changes since the implementation of the Basic Education Reform in 1998. One aspect of recent curricular reform in Oman has been the introduction of life skills. The curriculum for LS covers seven areas of learning: personal skills, citizenship, health and safety, home culture, world of work, social skills and universalism. Each of these areas embraces knowledge, skills and activities related to technology, career counseling and guidance, and general life skills. The goal of LS when it was first introduced into the Omani school system was mainly to link school learning with the student's local environment characteristics and needs. Another goal was to ensure the transfer of skills and knowledge into the students' practical world (Ministry of Education, 2001, 2006, 2012).

One of the aims of the educational system in Oman is to produce effective and productive citizens who are able to deal with continuous technological developments and changes in life styles. Accordingly, the main rationale for introducing Life Skills (LS) in the basic education is to prepare students who are technologically oriented, expose them to real life skills in order to improve their daily life and home environment, and enable them to better appreciate craftsmen and manual work (Rassekh, 2004; Al-Nofli, 2010; Issan and Gomaa, 2010: UNESCO, 2002; Ministry of Education, 2001, 2006, 2012).

LS has had a short history of development in the Omani system of Education, unlike analogous programs in other countries such as the USA, Jordan and the UK. LS began to be taught at the basic education school level during the early part of the 2000 s. The goal of integrating the study of technology and life skills into the curriculum of all the grades at the basic education has continued to the present day, with the explicit purpose of helping children to better understand their world, the world of work and technology, and the ways of how to benefit from using technology in their everyday life. The curriculum at this stage, which comprises an introduction to simple skills related to technology and daily life skills and careers, encourages students to follow a healthy life style, deal with the products of modern technologies and local environmental issues, and improve their coordination through manual activities. It com- prises the subjects of health and nutrition, life skills, general safety and road safety, and some games (identified as 'vocational activities') that introduce simple vocational abilities (Volk, 2011; UNESCO, 2002, 1974). In short, this stage, which is termed as the career awareness stage, aims to achieve student awareness of personal and social requirements (Ulaimat, 1991; Hendrix, 1986). The curriculum at this stage is, therefore, not vocational in the conventional sense. Moreover, some of the skills included at this stage could be acquired in home life; for example the importance of food, personal hygiene, tidiness, and the cleanliness of vegetables (Ministry of Education, 2012; AI-N ofli, 2010; Issan and Gomaa, 2010)

The curriculum is delivered through a teacher's guide and students' workbooks. Students undertake written exercises and study theoretical concepts, in addition to learning about technology, life skills and careers. The curriculum guidelines state that LS is delivered at the first cycle of the basic stage by a teacher who is able to teach all subjects in grades 1-4. One course of three credit hours is provided at some Omani universities for the student teachers, who are studying to be teachers, whereas in some universities such a course is not in offer for pre-service teachers. This course is theoretical and usually delivered through lectures to a large class of students. Additionally, this course has no clear objectives in terms of the competencies to be acquired. Although there are no pre-service LS teacher education programs in Oman, extensive in-service training sessions on LS implementation are conducted regularly for the teachers who are assigned to teach LS as a school subject (Ministry of Education, 2012).

On the basis of the previous discussion, this study attempts to evaluate the delivery of LS at the first cycle of the basic stage in Omani schools in order to gain deep insight into why and how LS is being implemented. In the context of this study, the evaluation focuses on teachers' perception regarding their strengths and confidence in implementing LS activities, primary factors that affect teachers' initial involvement in LS, benefits of LS activities for children, how LS activities are being implemented, physical resources that teachers need in implementing LS activities, and barriers to the implementation of LS and how LS can find greater acceptance at the first cycle of the basic stage in the future. 


\section{Research problem}

All students in Omani schools are expected to study technology and life skills following a structured program of the curriculum from their first year at school through to year ten, the end of the compulsory basic education. The success of the LS curriculum at the first cycle of the basic stage depends upon its successful implementation at schools. Teachers are the crucial factor if successful implementation of LS curriculum is to be achieved.

The knowledge and skills related to the main fields of the Omani LS curriculum are increasing at an exponential rate. This denotes a continuous curriculum change which necessitates that teachers should adopt new methods of teaching and learning (Rassekh, 2004; Rohaan, Taconis and Jochems, 2010; Gibson, 2007). It also necessitates that LS teachers constantly acquire knowledge in order to cope with the ever-changing nature of the LS curriculum. The Ministry of Education in Oman emphasizes that the new curricula should foster critical thinking skills and problem solving capacity among students and provides opportunities for practical experience and application to real life situations. To introduce the change, international experts are consulted and appropriate scientific methods to plan and implement the desired change are used.

The researcher noticed several barriers to practicing LS teaching at Omani schools. A mong these barriers were the lack of materials, equipment and tools to carry out LS activities; the lack of administrative support for the implementation of LS; the lack of understanding of LS objectives and LS importance on the part of teachers; and the negative attitudes towards LS on the part of teachers, administrators and parents. Little education research was identified among major problems facing the education system in Oman at the beginning of the twenty-first century. Hence, the need to identify the value of LS and to find ways to ease its implementation is clear. A three-credit-hour undergraduate course is usually offered at Omani universities for student teachers who are studying to be teachers at the first cycle of schooling. This raises the question of whether teachers at the first cycle of schooling are qualified to teach LS. This study attempts to discover the prevalence and status of LS in the classrooms in Omani schools, in order to understand why and how LS is being imple- mented and how LS can find greater acceptance at the first cycle of schooling in the future.

\section{Purpose of the study}

The purpose of this study is to gather data from school teachers who are appointed by the MoE in the Sultanate of Oman to deliver LS at the first cycle of the basic stage (grades 1 to 4). Information was sought relative to teachers' background and past experience in LS, their current teaching experience of LS, and their opinions about LS. The success of LS introduction into the first cycle of the basic stage in the Sultanate of Oman rests on the ability of teachers to make full use of the different LS resources to meet their particular teaching and learning goals. In addition, the success of LS delivery depends on the extent to which teachers themselves feel confident of the delivery of LS. Therefore, this study comes to evaluate the level of teachers' ability to deliver LS at the first cycle of schooling. Given current teachers' levels regarding the delivery of LS, what kind of needs can be identified in relation to teachers' own development and what kind of support do practicing teachers consider will be important if they are to be able to effectively deliver LS at the first cycle of the basic education and hence be able to raise the status of this subject at basic schools.

The researcher attempts to describe teachers' perceived benefits of and threats to LS activities and the confidence level teachers had with LS instruction and content. Teachers' attitudes towards LS and the extent to which they implement various facets of LS (technology, life skills and careers) were to be identified.

\section{Significance of the study}

The success of LS depends mainly on the attitudes and perceptions of all those involved in its implementation, especially teachers. There fore, the investigation of teachers' views on the different aspects of LS has been a central part of this study. Identifying factors that inhibit the proper delivery of LS at the first cycle of the basic stage in Omani schools will assist $\mathrm{MoE}$ and teacher education institutions to make informed decisions and orchestrate their efforts regarding the proper implementation of LS at the first cycle of the basic stage. To the best of the researcher's knowledge, there is no prior study that investigated the status of LS at the first cycle of basic education in Oman. 
Therefore, this research will contribute to the body of the literature concerning LS in Oman and other countries providing analogous programs.

\section{Limitations}

This study has the following limitations and delimitations:

1.The study is confined to evaluating the implementation of LS at the first cycle of the basic stage in Omani schools.

2. The study reflects the perceptions of Omani school teachers who teach at the first cycle of the basic stage during the 2nd semester of the 2010/ 2011 academic year.

3. The validity and the reliability of the study are limited by the honesty of the participants' responses to the instrument used in this study.

4. The majority of teachers at the first cycle of the basic stage in Oman are females. Hence, $94 \%$ of the selected sample was predominantly females.

5. Since the participants' perceptions may change in accordance with alterations in their gender, environments, qualifications and experiences, repeatability may not be at the level we wish.

6. The process of data collection related to this study was jointly conducted between the researcher and LS supervisors at educational directorates. Therefore, it was difficult to standardize the procedure of data collection, and hence there may have been some differences in the experimenter's treatment of the participants during the administration of the questionnaire

7. The study was carried out in Oman. However, results of this study can be generalised to other similar populations in the Arab countries offering analogous curricular area at the first cycle of the basic education.

\section{Research questions}

To achieve the objectives of the study, the following questions were raised:
1. What are the types of LS activities that teachers use in classrooms at the first cycle of the basic education?

2. What are the implementation approaches that teachers adopt in the delivery of LS activities at the first cycle of the basic stage?

3. What are the significant benefits of LS activities for children as perceived by teachers at the first cycle of the basic stage of schooling?

4. What are the factors that affected teachers' initial involvement in LS?

5. What are the physical resources needed by teachers for implementing LS activities at the first cycle of the basic stage?

6. What are the factors that teachers perceive to be the greatest barriers to the implementation of LS at the first cycle of the basic stage?

7. How confident are teachers regarding various aspects of LS content and instruction?

8. What are the factors that teachers believe to be most beneficial for promoting LS at the first cycle of the basic stage?

9. What opinions do teachers hold about curricular role of LS at the first cycle of the basic stage?

\section{Literature review}

Many people in the field of education believe that students must have experiences that are relevant to the present and that prepare them to live in the future (Gerbracht and Babcock, 1969; Minton and Minton, 1987). Current understandings of LS emphasize that technology has to be taught to all students beginning in the earliest school years. The term "LS" in school is used to include all forms of activities that involve children from grade one through four in hands-on, experiential activities that promote their understanding of the world of technology in which they live. LS also includes activities which aim to provide students with daily living skills and useful health habits (Rassekh, 2004; AI-N ofli, 2010; UNESCO, 2002, 1974; Twaisat, 1998; Al-Saydeh, 2002; AlSa'aideh, 2008; Ministry of Education, 2012). Such activities include design and manipulation of materials, problem-solving, and other 
activities that engage students in active inquiry about technology and everyday living skills.

LS is seen as integrating knowledge and skills from a variety of disciplines (AI-N ofli, 2010; Reid, 2000). Although many believe so, LS in school is not a secondary-school vocational education reduced in difficulty. LS includes a constructive endeavor in the design and manipulation of materials and tools (Gerbracht and Babcock, 1959; Williams, 2000; Ministry of Education, 2012). LS has the unique ability to integrate and provide relevance to other disciplines such as science and mathematics in schools. Consistent with this argument, many LS professionals indicate that LS and similar technology education programs should serve as a constructive methodology to teach other school subjects (Foster and Wright, 1996; Masri, 1993).

Foster (1997) and Volk (1996, 2011) numerate a number of benefits of LS and technology education for children. These benefits include practice with perceptual and motor skills, and skills such as graphic representation, visualization, design and tool use; improved technological knowledge and capabilities; development of vocabulary, language use, and creative communication; and improved social and life skills such as engagement, responsibility, personal growth, and the ability to work with others. In addition, LS and similar practical provisions have the potential to relate the knowledge and skills students learn in other subjects to their everyday life practices (Twaisat, 1998; Al-Saydeh, 2002; Al-Sa'aideh, 2008; Rassekh, 2004).

The success of LS implementation in schools rests in the hands of teachers. However, the role of teachers has shifted from imparting knowledge to facilitating the learning process. Information and Communication Technology (ICT) has a great potential in aiding teachers to adapt to this role shift (Safari, 2011; A buhmaid, 2011; Resta et al, 2002; Saud, Shuaibu, Tahir, Buntat, Yahaya, and Gital, 2011). For instance, teachers' inquiry can befacilitated with the help of computers as they provide access to vast amounts of information. Through the use of E-mail, user groups, and other online forms, LS teachers have the opportunity to communicate and share their experiences with a much wider range of colleagues and experts in the field of LS. The World Wide Web can facilitate teachers' access to digital libraries and vast amounts of information in printed, visual and video form. Video conferencing offers teachers the opportunity to observe other teachers in different countries as they implement similar curriculum areas and learn from their expertise (Gibson, 2002; Safari, 2011; Abuhmaid, 2011; Resta et al, 2002; Saud, Shuaibu, Tahir, Buntat, Yahaya, and Gital, 2011). Nonetheless, the use of ICT cannot be fully effective unless teachers receive adequate training and support (Safari, 2011; A buhmaid, 2011; Resta et al, 2002; Saud, Shuaibu, Tahir, Buntat, Yahaya, and Gital, 2011; \& Resta, Anderson, Davis, Muranov, Thomas, and Uvarov, 2002). In addition, teachers' skills and competencies should be continuously updated to keep current with most recent innovations in this area so they can transfer these competencies to students (Resta, et al, 2002 ; Reid, 2000).

To enable teachers to utilize ICT, pre and inservice teacher training institutions need to undertake a more active role with regard to teacher training that goes beyond the development of basic ICT literacy skills to educationally oriented training of ICT. This entails that teacher educators and trainers should model the appropriate use of ICT in the delivery of the curriculum of teacher education and training programs inasmuch as teachers are required to incorporate ICT into their own teaching of LS at schools (Gibson, 2002; Reid, 2000; Lynch, 2000; Safari, 2011; A buhmaid, 2011; Resta et al, 2002; Saud, Shuaibu, Tahir, Buntat, Yahaya, and Gital, 2011).

Another approach to help teachers grasp the basics for teaching their subjects could be achieved through the integration of the principles of constructivism in both pre-service and in-service teacher education and training programs. Constructivism is a theory that de monstrates learning as an active construction of knowledge through experiences and direct interaction with the local environment and context dependent activities (Kozulin, 1998). The theory necessitates that teachers be provided with opportunities that allow them to acquire skills and knowledge in a real world context and authentic activities. This constructivist process to teacher education and training is deemed essential if we are to help teachers to develop problem solving and critical thinking skills and empower them with the ability to apply, analyze, synthesize, and evaluate 
knowledge skills and attitudes (Lynch, 2000; White, 1995; Fox-Turnbull and Snape, 2010).

Most researchers agree that effective teaching of technology requires a wide range of teaching methods, e.g., inquiry learning, collaborative learning, and cross-curricular learning (Rohaan, 2010). This entails that teachers should possess such teaching methods to effectively implement LS at schools as teaching methods are one of the factors that enhance effective learning and teaching in technology education. The teaching method or pedagogical approach adopted by teachers affects pupils' learning and attitude. Stables (1997) suggests that the 'hands-on' exploration in the context of problem solving, in which pupils think and do, is the best way of teaching technology and similar practical programs in schools. Twyford and Jarvinen (2000) advocate the use of 'hands-on' approach in teaching students at the first cycle of schooling. However, the researchers emphasized that in order to boost pupils' understanding of technology the presented activities should be authentic. Benson and Lunt (2011) contended that the opportunity for hands-on, practical work in Design \& Technology is imperative for promoting children's creativity. Weber and Custer (2005) found that both boys and girls were more interested in 'doing' activities. Volk et al ( 2003) found that innovative technology programs, with less handicraft-based and promoting creativity, problem-solving, and collaborative skills had larger effects on pupils' attitudes than more traditional programs.

A nother important aspect relating to teachers' ability to implement LS is knowledge of the nature and purpose of LS. This aspect greatly affects what the teacher highlights as important (Jones and Moreland, 2004) and, in turn, what the pupils learn. Teachers' attitude towards technology and self-efficacy in teaching technology are important factors. In a study that aimed to broaden pre-service teachers' perceptions of technology by engagement in a technology unit of study, many teachers reported they had achieved enough confidence and capability to teach technology in primary schools (McRobbie et al. 2000). This implies that enhanced knowledge of the subject is related to enhanced confidence in teaching the subject.

On the whole, Pedagogical Content knowledge (PCK) is a vital domain of teacher know- ledge. The $\mathrm{N}$ ew Zealand researchers Jones and Moreland (2004) found that enhanced teachers' PCK increases pupils' motivation and interest in technology. The results of several other studies in primary technology education (Fox-Turnbull, 2010; Stein et al., 2002) and primary science (Davis, 2004) are in line with this finding.

Fox-Turnbull and Snape (2010) conducted a study that aimed at investigating the effect of a constructivist-based authentic practical activity within an initial teacher education programme in New Zealan. The results revealed increased student teachers' understanding of technology education and authentic technological practice.

Wilson and Harris (2003) identified some other factors that would contribute to the effective delivery of LS and the enhancement of learning and teaching in this area. These include the up-to-date continuing professional development and management support to allow school teachers to implement innovative practices, and the appropriate curriculum content and teaching methods, adequate equipment and accommodation.

The provision of analogous programs, technology education, LS, PVE, craft education, industrial arts etc, worldwide appears to suffer from several problems (AI-Saydeh, 2002; AISa'aideh, 2008; Twaisat, 1998; Masri, 1993; Özden, 2007; Gibson, 2007) revealed a host of problems and challenges encountering the delivery and implementation of this subject. Examples of such problems include: poorly prepared teachers, lack of facilities required for the delivery of practical activities, lack of administrative support for this subject, and negative attitudes teachers, administrators, lack of time to implement practical activities, crowded classrooms, and parents' negative attitudes towards such provision. These studies ascribe the problems hindering the effective delivery and implementation of these programs to the failure of pre and in-service teacher education programs that focus on the de-contextualized delivery of the curriculum content prescribed for teachers in these programs.

The review of research has shown that LS education is generally considered to be essential for children at the first cycle of the basic stage. A need to familiarize children with technology, life skills and careers has also been demon- 
strated. The reviewed studies also revealed several weaknesses in practical provisions analogous to LS worldwide. Nonetheless, there are no studies conducted in Oman to investigate various facets of LS. Hence, a need to establish a research base in LS in Oman is necessary. The need exists for school teachers at the first cycle of the basic stage to have LS knowledge and skills so they can transfer learning in the classroom to real world situations. Therefore, this study focuses on the skills, knowledge and perceptions of teachers related to various aspects of LS at the first cycle of the basic stage.

\section{METHOD}

\section{Population and sample}

The population of this study consists of all teachers teaching at the first cycle of the basic stage of schooling in Oman $(\mathrm{N}=2396)$ during the second semester of the academic year 2010/2011. A multi-stage random sampling approach was used to select 315 teachers, (295 females and 20 males), using the 2010/ 2011, ministry of education directory that listed all teachers at the first cycle of the basic education stage in Oman (Ministry of Education, 2011).

In the first stage of sampling, five out of eleven education directorates were randomly se lected. In the second stage, a random sample of two counties (Wilayah) was taken from within each of the five education directorates chosen in the first stage. All teachers in the ten selected counties (Wilayat) were selected as a sample for the study.

\section{Instrumentation}

A survey instrument is utilized to answer the research questions. The instrument is adopted and modified from an instrument developed by Kirkwood (2000) and in the A rab world by Twaisat (1998) and Al-Saydeh (2002). The re vised instrument is reviewed by a panel of experts. Members of the panel are selected because of their experience in LS and technology education, expertise in instrument development, expertise in the use of statistics, and expertise in the area of English-A rabic translation. The panel has examined all translated statements for appropriate language and word usage and made suggestions about item terminology to enhance clarity and brevity. The suggestions provided by the panel of experts are incorporated into the instrument development to the fullest extent possible.
In its final form, the survey instrument includes two sections, demographics and a fourpoint Likert scale designed to measure teachers' perceptions at the first cycle of the basic education stage relative to various facets of LS. The demographic section asked teachers for their gender, age, class level they teach, number of years as teachers, level of education, and number of undergraduate LS-relative courses taken by them. The second section, the perceptions scale, was designed to obtain information about teachers' perceptions regarding the status of LS at the first cycle of the basic stage through the use of 70 items, divided into nine areas. These areas include: activities used in classrooms (seven items), an example of the items in this area is "Make artifacts that illustrate major aspects (of the curriculum)" , implementation approaches for LS activities (five items), an example of the items in this area is "I focus on the local environment in the design and implementation of LS activities", the significant benefits of LS (nine items), an example of the items in this area is "Promotes students practice of good habits (hand and face wash, and bathing) after performing LS activities", initial involvement with LS activities (five items), an example of the items in this area is "Attended a presentation, workshop, or other in-service meetings", physical resources (twelve items), an example of the items in this area is "Internet access", barriers to implementation (eleven items), an example of the items in this area is "Lack of appropriate equipment and supplies" teachers' perception of their own ability to implement LS activities (ten items), an example of the items in this area is "I feel I need more training in LS in order to implement it effectively", ways to increase the implementation of LS (eight items), an example of the items in this area is "Developing a web site that caters to LS implementation" , and curricular role of LS (three items).

All items of the perception scale are close ended, requiring responses on a four-point Likert scale with the following descriptors: "strongly agree," "agree," "disagree," "strongly disagree" The responses were assigned numerical values from 1 (strongly disagree) to 4 (strongly agree). For the responses on the area of curricular role of LS of the perception scale, respondents are asked to select one of the following three options: "LS should be an optional part of the curriculum," "LS should bea compulsory part of the curriculum," and "LS 
should not be part of the curriculum". This section is analyzed, using frequencies and percentages. In an effort to test the appropriateness of the language and word usage of the instrument, along with a determination of its validity and reliability, a pilot study is conducted. The teachers selected for the pilot study $(n=57)$ are not included in the main study. In addition to completing the instrument, the teachers are asked to circle any words they do not understand and to indicate any difficulties they have in completing the instrument. Modifications to the instrument are made, with consideration given to the original intent of the instrument with the guidance of the panel of experts.

Muller (1986) mentions that tests with items scored along a continuum such as Likert scale require the use of Alpha. Cronbach al pha procedure is used to obtain the reliability estimate of the internal consistency of the perception measurement section of the instrument, which was found to be 0.85 . This value is considered acceptable in educational studies (Cohen, $\mathrm{Ma}$ nion, \& Morrison, 2000). The majority of the surveys (265 surveys) are distributed by LS supervisors who visit schools on a regular basis. This was done in collaboration with the technical office at the MoE in Oman. The rest of the surveys ( 50 surveys) are distributed by the researcher to each LS teacher in the schools. Participation in the study is voluntary and responses are kept confidential.

\section{D ata analysis}

To analyze data gathered from teachers, the questionnaires are first coded and then entered into SPSS. Mean scores and standard deviations are computed for responses for each item on the questionnaire. Frequencies and percentages are generated for the responses on the items related to the area of curricular role of LS. Tables are developed to present these results and are provided herein to allow interpretations of the data.

\section{RESULTS}

The main purpose of this study is to gather data from school teachers who teach LS at lower basic stage relative to various facets of LS delivery. Based on data analysis, the findings of the study are presented according to its questions.

\section{D emographics of the sample}

The demographic section of the survey instrument reveals that all respondents are licensed. Two hundred ninety five respondents (94\%) are females. As part of women empowerment in Oman, the majority of teachers appointed at the first cycle of the basic education are females. This has resulted in the sample being predominatntly female $94 \%$. The mean age of respondents is 31.9 years. The mean number of years they have taught is 9.27. Two hundred thirty respondents (73\%) had bachelor degree qualification. All respondents taught all of the core subjects except English. Mean class size is 29.18 students, with a range from 15 to more than 44 . Two hundred and thirty respondents reported that they had taken a course or two relevant to LS curriculum at the undergraduate level, whereas the remaining respondents reported that they had not taken any course relevant to LS curriculum at the undergraduate level.

Around $61.8 \%$ ( $n=195)$ of the respondents indicated that they possessed some experience related to LS teaching, whereas $14.3 \%(n=45)$ of the respondents indicated that they were experienced in LS teaching. The rest $23.8 \%$ $(n=75)$ indicated that they had a vague understanding of what LS is.

Two hundred eighty five (90.5\%) of the respondents reported that their academic qualification was relevant to LS curriculum, whereas $30(9.5 \%)$ of the respondents indicated that their academic qualification was not relevant to LS curriculum. Two hundred and fifty seven (82\%) of respondents had taken eight or more training sessions related to LS implementation, whereas fifty eight (18\%) of the respondents reported taking five to seven training sessions related to LS implementation.

\section{Activities used in classrooms}

Research question one: What are the types of LS activities that teachers use in classrooms? This question is answered by instrument items 1 through 7. In this section of the questionnaire, respondents are asked to check the response that corresponds to the degree of LS activities they use in classrooms. As shown in Table 1, of all the items related to this section, the mean score for responses related to items 1 "Engage students in a manipulative problemsolving activity" and 7 "Identify a specific problem in the classroom and design/ make a 
solution" have the lowest mean scores of 2.07 and 2.10 respectively, indicating "completely disagree" rating. The rest of the items in this section have mean scores ranging from 2.84 to 3.24 , indicating an "agree" rating. The mean score for all the items in this section is 2.78 , in the agreeing category.

\section{Implementation approaches for LS activities}

Research question two: What are the implementation approaches that teachers adopt in the implementation of LS activities at the first cycle of the basic stage? This question is answered by instrument items 8 through 12. As seen in Table 2, item 10 scores the lowest mean $(M=2.25)$, indicating a disagreement among respondents regarding the use of ICT in the implementation of LS activities. This result shows that teachers do not integrate ICT tools in LS instruction, nor do they design ICT based instructional materials related to LS. Responses for items 8, 11, and 12 reflect an agreement among respondents with mean scores ranging from 3.13 to 3.54 . These results suggest that teachers do not perceive LS as an independent subject, rather than a set of activities embedded in other subjects in schools.

\section{The significant benefits of LS}

Research question three: What are the significant benefits of LS activities for children as perceived by teachers? This question is ans- wered by instrument items 13 through 21 . Responses mean scores for items of this section indicate an agreement and a complete agreement on their part regarding the benefits of LS activities in schools. Mean scores for the items in this section range from 2.86 "promotes students' psychomotor development such as improving fine motor skills and building tool use skills" to 3.73 "Promotes students practice of good habits (hand and face wash, and bathing) after performing LS activities". These figures suggest that LS is a pivotal subject in schools and that LS activities can be effectively integrated into the curriculum.

\section{Initial involvement with LS activities}

Research question four: What are the factors that affect teachers' initial involvement in LS? This question is answered by instrument items 22 through 26. Table 4 shows that respondents agree that attending a presentation, workshop, or other in-service meetings, and taking an undergraduate class in LS are the most two influential factors in getting involved with LS activities. Items related to these factors have mean scores of 3.57 and 3.27, respectively. All items listed in this section have mean scores that range from 2.86 to 3.57 . This indicates that all factors are important in motivating teachers to get involved in LS activities.

Table 1

Means and Standard Deviations of Types of LS Activities Used in Classrooms (Ranked in a Descending Order)

\begin{tabular}{clcc}
\hline Item & LS activity & Mean & Standard deviation \\
\hline 2 & Make artifacts that illustrate major aspects (of the curriculum) & 3.24 & 0.79 \\
3 & $\begin{array}{l}\text { Design/ make puppets and/ or scenery for a classroom play } \\
\text { Design/ make a model village, city, house, vehicle or other artifacts of }\end{array}$ & 3.17 & 0.77 \\
5 & $\begin{array}{l}\text { a past, present or future culture } \\
\text { Make a model or simple apparatus that demonstrates a technological } \\
\text { principle such as simple machines, bridges, etc. }\end{array}$ & 2.11 & 0.80 \\
& $\begin{array}{l}\text { Design/ construct manipulatives for math and other school subjects } \\
\text { activities }\end{array}$ & 2.84 & 0.86 \\
7 & $\begin{array}{l}\text { Identify a specific problem in the classroom and design/ make a solu- } \\
\text { tion for it }\end{array}$ & 2.10 & 0.84 \\
1 & Engage students in a manipulative problem-solving activity & 2.07 & 1.10 \\
\hline
\end{tabular}

Table 2

\begin{tabular}{clcc}
\multicolumn{2}{c}{ M eans } & M eans and Standard D eviations of M ethods of Implementing LS Activities (Ranked in a Descending Order) \\
\hline Item & Method of implementation & Mean & Standard deviation \\
\hline 12 & I focus on the local environment in the design and implementation of LS & 3.54 & 0.79 \\
& activities & 3.37 & 0.90 \\
11 & I adhere to safety standards when I deliver LS activities & 0.86 \\
& Activities are integrated with class instruction on a periodic basis when & 3.13 & 0.94 \\
& they conveniently and/ or appropriately fit in with the curriculum & 2.41 & 0.82 \\
10 & I take all the decisions concerning the delivery of the psychomotor skills & 2.25 &
\end{tabular}


Table 3

M eans and Standard Deviations for the Perceived Benefits of LS (Ranked in a Descending Order)

\begin{tabular}{|c|c|c|c|}
\hline Item & Benefit & Mean & Standard deviation \\
\hline 17 & $\begin{array}{l}\text { Promotes students practice of good habits (hand and face wash, and } \\
\text { bathing) after performing LS activities. }\end{array}$ & 3.73 & 0.48 \\
\hline 19 & Develop students' social relationship through teamwork & 3.68 & 0.53 \\
\hline 14 & $\begin{array}{l}\text { Provides students with opportunities to apply concepts and skills } \\
\text { from many disciplines such as math, science, and language arts. }\end{array}$ & 3.52 & 0.64 \\
\hline 20 & $\begin{array}{l}\text { Helps identify students' personality characteristics during the ca- } \\
\text { reer awareness stage. }\end{array}$ & 3.51 & 0.53 \\
\hline 15 & $\begin{array}{l}\text { Helps students learn to identify, solve, and evaluate practical prob- } \\
\text { lems. }\end{array}$ & 3.44 & 0.61 \\
\hline 13 & $\begin{array}{l}\text { Builds lifel ong skills such as problem solving, creative thinking, } \\
\text { and self-directed learning. }\end{array}$ & 3.19 & 0.91 \\
\hline 16 & $\begin{array}{l}\text { Promotes students' affective development such as improving self- } \\
\text { esteem and motivation to learn. }\end{array}$ & 3.17 & 0.70 \\
\hline 21 & $\begin{array}{l}\text { Helps identify students' inclinations and interests during the career } \\
\text { awareness stage. }\end{array}$ & 3.10 & 0.61 \\
\hline 18 & $\begin{array}{l}\text { Promotes students' psychomotor development such as improving } \\
\text { fine motor skills and building tool use skills. }\end{array}$ & 2.86 & 1.21 \\
\hline
\end{tabular}

Table 4

M eans and Standard D eviations for the M ajor Factors Influencing Involvement with LS (Ranked in a Descending Order)

\begin{tabular}{clcc}
\hline Item & \multicolumn{1}{c}{ Major Factors } & Mean & Standard Deviation \\
\hline 24 & Attended a presentation, workshop, or other in-service meetings & 3.57 & 0.58 \\
22 & Took a class at the undergraduate level & 3.27 & 0.65 \\
25 & Learned about it by reading educational journals & 3.22 & 0.77 \\
23 & Observed other teacher(s) and liked what I saw & 3.10 & 0.99 \\
26 & $\begin{array}{l}\text { An administrator encouraged me to get involved in the implemen- } \\
\text { tation of LS activities. }\end{array}$ & 2.86 & 0.80 \\
\hline
\end{tabular}

Table 5

M eans and Standard Deviations For Physical Resources to Increase A bility to Teach LS Activities (Ranked in a Descending Order)

\begin{tabular}{|c|c|c|c|}
\hline Item & Desired Physical Resources for LS & Mean & Standard deviation \\
\hline 37 & Internet access & 3.78 & 0.49 \\
\hline 32 & Suitable Computer Devices & 3.76 & 0.46 \\
\hline 36 & $\begin{array}{l}\text { Other tools/ devices (sawing fixtures, drilling jigs, cutters, ovens, } \\
\text { etc.). }\end{array}$ & 3.75 & 0.50 \\
\hline 38 & Availability of a specialized website for LS on the Internet & 3.71 & 0.52 \\
\hline 30 & Physical space for implementing LS activities & 3.71 & 0.49 \\
\hline 28 & Commercial kits such as $K^{\prime} N$ ex ${ }^{\circledR}$, Lego ${ }^{\circledR}$, etc & 3.68 & 0.53 \\
\hline 29 & Storage space for storing LS gadgets, tools and equipment & 3.68 & 0.59 \\
\hline 31 & Work tables or other suitable work surfaces/ areas & 3.67 & 0.59 \\
\hline 34 & Hand tools (saws, hammers, drills, clamps, files, brayers, etc.). & 3.65 & 0.54 \\
\hline 27 & $\begin{array}{l}\text { General materials and equipment (wood, wheels, paper, batteries, } \\
\text { etc.). }\end{array}$ & 3.65 & 0.60 \\
\hline 35 & Water supply or sinks & 3.63 & 0.63 \\
\hline 33 & $\begin{array}{l}\text { Computer peripherals/ equipment digital cameras, scanners, printers, } \\
\text { etc.). }\end{array}$ & 3.60 & 0.66 \\
\hline
\end{tabular}

\section{Physical resources}

Research question five: What are the physical resources teachers need in implementing LS activities at lower basic stage? This question is answered by instrument items 27 through 38 . According to Table 5, respondents tend to agree that "internet access," "Suitable Computer Devices," "Other tools/ devices (sawing fixtures, drilling jigs, cutters, ovens, etc.).," "Availability of a specialized website for LS on the Internet," and "Physical space for im

plementing LS activities " are the most important physical resources for implementing LS. Items related to these physical resources have mean scores of 3.78, 3.76, 3.75, 3.7 and 3.71, respectively. None of the items in this section 
obtains a mean below the "agree" category. This indicates that all physical resources listed in this section can be helpful in the Jordanian schools for effective delivery of LS activities.

\section{Barriers to implementation}

Research question six: What are the factors that teachers believe to be the greatest barriers to the implementation of LS? This question is answered by instrument items 39 through 49 . The first 9 barriers, listed in Table 6, are believed to have made the implementation of LS difficult. The items related to "Lack of appropriate equipment and supplies" and "Insufficient financial support for doing LS activities" have achieved the highest mean scores of 3.75 and 3.70, respectively. Responses for the first 4 barriers related to this section have fallen in the "completely agree" category with mean scores ranging from 3.54 to 3.75 . This result indicates that these barriers contribute to an ineffective implementation of LS at the lower basic stage. However, two of the barriers item 46 "A bsence of national interest in LS" and item 45 "Lack of interest on my part to learn and implement LS content" have mean scores of 2.49 and 2.03 in the "disagree" category.

Teachers' perceptions of their own ability to implement LS activities

Research question seven: How confident are teachers regarding various aspects of LS con- tent and instruction? This question is answered by instrument items 50 through 59 . Respondents are asked to freely respond to the items in Table 7 by indicating the degree of their confidence in their ability in and how they felt about LS teaching. The overall mean score for this section is 2.94 , and the mean scores for the individual items, except item 57 , are more than 2.5. Items 57 "I feel capable and comfortable using the problem-solving approach in LS" have achieved the lowest rating with a mean score of 2.24. The rest of the items in this section have mean scores ranging from 2.71 to 3.43. This result indicates respondents' agreement with the content of the items in this section, except item 57.

\section{Ways to increase the implementation of LS}

Research question eight: What are the factors that teachers perceived to be most beneficial for advancing LS at lower basic stage? This question is answered by instrument items 60 through 67. Respondents are asked to indicate their level of agreement with 8 suggest ways that are considered to be the best and most effective ways in getting more teachers/ schools to implement LS. The results ( $\mathrm{Ta}$ ble 8) indicate that all the ways have mean scores greater than 2.5 which is above the "agree" category. Three items "Developing a web site that caters to LS implementation,"

Table 6

M eans and standard deviations of barriers to implementing Is activities (Ranked in a Descending Order)

\begin{tabular}{clcc}
\hline \multicolumn{1}{c}{ Barriers } & Mean & Standard deviation \\
\hline Item & & 3.75 & 0.47 \\
49 & Lack of appropriate equipment and supplies. & 3.70 & 0.49 \\
42 & Insufficient financial support for doing LS activities. & 3.62 & 0.68 \\
41 & Inadequate space in classroom to do LS activities. & 3.54 & 0.69 \\
47 & Insufficient planning time to prepare for LS activities. & 3.48 & 0.82 \\
43 & Inadequate or insufficient training/ expertise in the LS area. & 3.41 & 0.77 \\
44 & Inflexibility of local or state curriculum. & 3.37 & 0.65 \\
49 & Lack of parental support. & 2.73 & 0.86 \\
48 & Lack of support from other teachers. & 2.60 & 0.90 \\
46 & Absence of national interest in LS. & 2.49 & 0.80 \\
45 & Lack of interest on my part to learn and implement LS content. & 2.03 & 1.11 \\
\hline
\end{tabular}

Table 7

M eans and standard Deviations of Teachers' Satisfaction Concerning Their $\mathbf{O}$ wn A bility and Attitude toward I mplementing is ((Ranked in a D escending Order)

\begin{tabular}{|c|c|c|c|}
\hline Item & Items & Mean & Standard deviation \\
\hline 52 & I feel I need more training in LS in order to implement it effectively. & 3.43 & 0.81 \\
\hline 59 & I enjoy LS teaching. & 3.40 & 0.79 \\
\hline 53 & I think I understand most of the technical content involved in LS. & 3.21 & 0.69 \\
\hline 51 & I think I have the expertise needed to teach LS. & 2.98 & 0.86 \\
\hline 54 & I feel capable and comfortable using LS tools such as saws, hammers, drills, etc. & 2.97 & 0.74 \\
\hline 56 & I feel capable and comfortable doing LS processes such as cutting, assembling, etc. & 2.87 & 0.79 \\
\hline 58 & I feel prepared to develop new activities for my students. & 2.83 & 0.79 \\
\hline 55 & I feel capable and comfortable using LS materials such as wood, cardboard, plastic, etc. & 2.75 & 0.84 \\
\hline 50 & Overall, I feel capable and comfortable teaching LS & 2.71 & 0.72 \\
\hline 57 & I feel capable and comfortable using the problem-solving approach in LS. & 2.24 & 0.97 \\
\hline
\end{tabular}


Table 8

M eans and Standard Deviations of Ways to Increase Implementation of is (Ranked in a Descending Order)

\begin{tabular}{|c|c|c|c|}
\hline Item & Ways to implement LS & Mean & Standard deviations \\
\hline \multirow{2}{*}{$\begin{array}{l}67 \\
62\end{array}$} & Developing a web site that caters to LS implementation & 3.57 & 0.56 \\
\hline & $\begin{array}{l}\text { Publishing more LS curriculum materials in line with recent } \\
\text { technological innovations }\end{array}$ & 3.54 & 0.56 \\
\hline 66 & Preparing specialized LS teachers for the lower basic stage & 3.54 & 0.59 \\
\hline 63 & Offering more undergraduate courses in LS for teachers & 3.49 & 0.59 \\
\hline 64 & $\begin{array}{l}\text { Providing more training specifically for administrators to fami- } \\
\text { liarize them with the importance of LS }\end{array}$ & 3.49 & 0.61 \\
\hline 60 & Offering more workshops (in-service, summer, etc.) in LS & 3.48 & 0.92 \\
\hline 65 & Publishing more articles about LS in journals and magazines & 3.44 & 0.59 \\
\hline 61 & $\begin{array}{l}\text { Offering more LS workshops and interest sessions at confe- } \\
\text { rences }\end{array}$ & 3.41 & 0.73 \\
\hline \multicolumn{4}{|c|}{ Table 9} \\
\hline \multicolumn{4}{|c|}{ Frequencies and Percentages of The Role of LS in the Curriculum as Perceived by Teachers } \\
\hline Item & $\begin{array}{l}\text { Opinion } \\
\end{array}$ & Frequency & Percentage \\
\hline 68 & It should be a compulsory part of the curriculum & 271 & 86 \\
\hline 69 & It should not be part of the curriculum & 10 & 3 \\
\hline 70 & It should be an optional part of the curriculum & 34 & 11 \\
\hline
\end{tabular}

"Publishing more LS curriculum materials in line with recent technological innovations," and "Preparing specialized LS teachers for the lower basic stage" have received a rating in the "completely agree" category with mean scores of 3.57, 3.54 and 3.54, respectively. The respondents' ratings for the rest of the ways rest of the ways have fallen in the "agree" category. They have achieved mean scores ranging from 3.41 to 3.49. The overall mean score for this section is 3.50. This result indicates that the respondents' overall rating for this section have fallen in the "completely agree" category.

\section{Curricular role of LS}

Research question nine: What opinions do teachers hold relative to curricular role of LS at lower basic stage? This question is answered by instrument items 68 through 70. Respondents are categorized into three groups: those who think that LS should be required, those who think that LS should be optional, and those who think that LS should not be part of the lower basic stage curriculum. Frequencies and percentages for the three groups, which are presented in Table 9, show that the majority $(86 \%)$ of respondents $(\mathrm{N}=271)$ thought that LS should be a required part of the lower basic stage curriculum. They also show that only $3 \%$ $(\mathrm{N}=10)$ thought that LS should not be part of the lower basic stage curriculum and that, $11 \%$ $(\mathrm{N}=34)$ believed that $\mathrm{LS}$ should be an optional part of the lower basic stage curriculum. These results indicate a favorable view towards LS being a necessary part of lower basic stage curriculum.

\section{DISCUSSION}

A bove seventy-five percent of the respondents indicate that they are either experienced or possessing some experience related to LS teaching, whereas the rest indicate that they have a vague understanding of what LS is. Well above two-third of teachers graduated from a program that included a three-credithour LS course. However, for those who have a vague understanding about LS, the undergraduate LS course might not have been enough to familiarize them with the philosophy and objectives of the multiple areas covered in LS. This indicates that more courses relevant to LS teaching at the first cycle of the basic schools have to be offered at the universities. Another reason for the vague understanding of LS among some teachers could be ascribed to their schools' policy that might not have been supportive of LS implementation due to lack of awareness among school administrators regarding the philosophy and objectives of LS. Nevertheless, it is promising to see that over three-quarters of the respondents are either experienced or possess some experience related to LS teaching.

The results (shown in table 1) related to the "types of LS activities teachers use in their classrooms" reveal a relatively high rate. These results indicate that the most popular activity area in LS is "the design/ make a model village, city, house, vehicle or other artifacts of a past, present or future culture" is clearly 
the most popular LS activity in Omani schools. However, teachers do not agree on the items related to problem solving approach. This indicates that teachers are not successful in adopting problem-solving approaches in the implementation of LS activities. This result might be ascribed to ineffective pre-service and in-service teacher education and training programs. Such programs appear to have been devoid of problem-solving activities that, in turn, empower LS teachers to adopt such activities, which are considered vitally important in teaching. The MoE in Oman emphasizes that the new LS curriculum should foster critical thinking skills and problem solving capacity among students and provides opportunities for practical experience and application to real life situations. This necessitates an implementation approach of LS curriculum where the problems pupils solve in classrooms should be related to the pupils themselves and enables them to create appropriate and meaningful connections, i.e authentic activities (Schwarz, 1996; Fox-Turnbull and Snape, 2011). Pupils need to be encouraged to observe and solve problems in their everyday environment and they should be given an opportunity to apply their knowledge and skills in LS lessons. AISaydeh (2002) argues that a three-credit-hours course might not be sufficient to equip primary teachers in Jordan with the necessary knowledge and competencies to adopt problemsolving approach in the implementation of prevocational education at the lower basic stage. This statement applies to the situation in the Sultanate of Oman. To foster teachers' ability in this respect, teacher trainers should model the appropriate use of the problemsolving approach during in-service training session conducted for teachers. Since LS is a multi-disciplinary subject, a viable option to its proper delivery could be through the adaptation of team teaching approach. This result also implies that it is difficult to prepare one teacher to teach all LS fields. This necessitates an investigation of the possibility to teach LS by a team of teachers. Such investigation should address the context that makes it necessary to adopt team teaching in LS, identified the teachers who might participate in the team, and their levels of ability to collaborate in teaching each of the LS areas. It also should identify the difficulties and the required managerial and curricular changes.
According to the Ministry of Education (2012), Rassekh (2004), LS is a subject that should be taught independently from other school subjects. Results (displayed in Table 2) shows that teachers do not perceive LS as an independent subject; rather, they consider it a set of activities embedded in other subjects. Teachers' perceptions regarding the delivery approach emphasize what is termed by Masri (1993) as "integrated approach" to LS delivery. This suggests that the MoE needs to put in more efforts for the implementation of LS at the first cycle of the basic stage. Another important conclusion based on these findings is the teachers' ratings relating to the use of ICT in imple menting LS activities. Item 10 "I design instructional software programs for LS lessons and activities" has received the lowest rating. This again might be ascribed to inefficiency of teacher education and training programs to equip teachers with the necessary ICT skills to enable them to incorporate ICT tools in their instruction.

A consensus among teachers concerning LS benefits at the lower basic stage is observed. Their response rating on all items representing LS benefits ranges between "Agree" and "Strongly agree". They believe that promoting students practice of good habits (hand and face wash, and bathing) after performing LS activities and developing students' social relationships through teamwork are the greatest benefits. This response shows that teachers are aware of the benefits of LS activities for students. It also indicates that teachers consent that the role of LS goes beyond simply having children practice some manual skills and simple activities. This result supports the findings of Kirkwood and Foster (1999). This result also indicates that teachers recognize that working collaboratively should be an important feature of children's experience in LS. Having the opportunity to work collaboratively with others is a frequently cited feature of teaching for creativity. Fox-Turnbull (2010) highlights the importance of dialogue in the creative processes of practical activities: "When people work together in problem solving situations they do much more than just talk together. They 'interthink' by combining shared understandings, combining their intellects in creative ways, and often reaching outcomes that are well above the capability of each individual." (p. 26). 
Responses regarding the influential factors category indicate that teachers agree on a list of these factors that contribute to their involvement in LS. However, they believe that attending a presentation, workshop, or other in-service meetings and taking an undergraduate class in LS were the most influential factors. The LS teachers' agreement on these influential factors entails that the MoE in the Sultanate of Oman has to conduct more presentations and workshops relevant to LS teaching to encourage more involvement among LS Teachers in LS activities and reinforce their capacity as relates to LS delivery at schools.

Respondents agree that "internet access," "suitable computer devices," "Other tools/ devices (sawing fixtures, drilling jigs, cutters, ovens, etc.)" "Other tools/ devices (sawing fixtures, drilling jigs, cutters, ovens, etc.)" and "physical space for implementing LS activities," are the most important physical resources needed for implementing LS. The teachers clearly feel that more physical re sources are needed in order for the program to improve. In other words, they are willing to more effectively implement LS activities if the resources are available. Yet the lack of necessary resources seems to be a problem shared with LS in most other countries (Kirkwood, 2000; Gibson, 2007). The analogous subjects LS, PVE, Craft, Handicraft, Technology Education, etc. are universally the most costly school subjects. Efforts to change the attitudes of financial decision makers must continue, along with the efforts by teachers to convincingly demonstrate the values of LS program relative to the cost. Needs for computers and internet have received more responses than have storage space, worktables, and physical space. This result implies that the curriculum content for LS might be in need of upgrading to be in line with recent technological developments, especially in the area of ICT. The results also suggest that, for teachers, LS is a school subject in which students design and make products by using different materials, machines, processes, techniques and tools in addition to computers and internet use. Foster and Kirkwood (1994) come to conclusion that practical technological activities for children were about solving problems with their minds and building solutions with their hands.

Results from the section related to the barriers to LS implementation at the first cycle of basic stage of schooling in Oman indicated consis- tency with the results from the physical re sources section. "Lack of appropriate equipment and supplies" and "insufficient financial support for doing LS activities" are seen by teachers as the major obstacles to LS imple mentation. These results suggest that in order to increase the implementation of LS activities, MoE in Oman needs to prioritize equipping schools with the needed physical resources and equipment in addition to computers and internet connections. Teachers first need physical space, work surfaces and time coupled with the materials needed for the delivery of LS activities. Computers and computer peripherals, along with various hand tools such as pliers, saws, hammers, and general equipment such as ovens and fridges can effectively consolidate the delivery of the subject.

The results related to the section that deals with teachers' degree of agreement with statements about their own ability and attitudes toward implementing LS are promising. All the responses related to this section fell in the "disagree" category, indicating positive attitudes and high level of competence among teachers. This result shows a promising potential among teachers which will, in turn, affect students' attitudes positively. LS teachers' confidence in the delivery of LS activities and positive attitudes towards their subject play an important role in developing students' creativity and inculcating positive attitudes in them. Davies (2000) concludes that secondary technology teachers impede creativity in their pupils if they themselves lack confidence in their understanding of creativity in technology education. In addition, teachers with low confidence fail to encourage pupils, and this, in turn, leads to a negative attitude towards technology education among students. Similarly, Rohaan et al (2010) conclude that a teacher who has a negative attitude towards technology or has little confidence in teaching technology, reflects this in the classroom, and in turn affects pupils' attitude towards technology. Nonetheless, there is one exception related to LS teachers' confidence represented by item 57 "I feel capable and comfortable using the problem-solving approach in LS." Teachers view themselves as incapable and uncomfortable using problem-solving approach in the implementation of LS activities. These results reinforce the results obtained in the sections related to the types of LS activities delivered at the first cycle of the basic stage 
and the delivery approach of LS adopted by teachers. Teachers should focus on problemsolving approaches in which critical thinking is emphasized to teach LS (Rohaan et al 2010). In addition, as Stables (1997) recommends, teachers of practical subjects should focus on 'hands-on' exploration in the context of problem solving, in which pupils are thinkers as well as doers, as the best way of teaching practical subjects in schools. Twyford and Järvinen (2000) assert that students' understanding of technology can best be achieved when the presented problems are authentic. This entails that teacher educators and trainers should model problem-solving approaches in the delivery of the curriculum of teacher education and training programmes inasmuch as LS teachers are required to adopt this approach into their own teaching of LS at schools. Apart from teachers' inability to adopt problem-solving approaches, the results from this study are in accordance with research results on teachers introducing technology in their classrooms in New Zealand, which show that teachers have very high levels of pedagogical knowledge and are highly effective practitioners (Jones and Moreland, 2004). The results of this study are not similar to the ones found by Twaisat (1998), AlSaydeh (2002), and Gibson (2007). The results also do not support the results found by several other studies conducted worldwide (Kirkwood, 2000). These studies ascribe the problems encountering the effective delivery and implementation of similar programs to non-conducive pre and in-service teacher education programmes which focus on decontextualized delivery of the curriculum content prescribed for teachers and undergraduates. In the Jordanian context, Masri (1993) argues that the negative attitudes towards PVE and the non-supportive school environment to deliver PVE activities greatly hinder the effective delivery of this practical subject in Jordanian schools. MoE in Oman needs to provide specific on-going LS related training that would enable teachers to implement LS activities more efficiently. Also, in order for teachers to keep up with constantly changing LS related materials and equipment, they must be provided with the fiscal and technological resources necessary for the successful implementation of LS activities. However, even though the teachers are provided with current LS related resources, such as equipment and materials, they may still need incentives to encourage them to attend training sessions relative to LS instruction.

\section{CONCLUSION}

The results from this study reveal several strengths and weaknesses in the implementation of LS at the first cycle of the basic stage of schooling in Oman.

There are several factors that may help make LS more prevalent at the first cycle of the basic education. The most important factor considered by teachers in developing a web site that caters for LS implementation and would promote LS delivery at the first cycle of the basic stage. Such website will help teachers to access a vast amount of LS related information in the areas of planning, assessment, and approaches to delivery which may facilitate the implementation of this subject. Publishing more LS curriculum materials in line with re cent technological innovations has received the second most important factor that would promote the implementation of LS at the first cycle of the basic schooling. This result implies the need for more innovative approaches to curriculum content.

Preparing specialized LS teachers for the first cycle of the basic stage has received the third most important rating. This could be a viable option that would contribute to the effective delivery of LS at this stage. Alternatively, a team teaching approach to LS delivery could be adopted where specialized LS teachers at the second cycle of the basic stage can collaborate with and support teachers in the implementation of LS activities.

The reported lack of skills in and knowledge about LS among teachers is reflected in the goals they have for their students. In other words, if teachers themselves are not skilled in an area, they do not see it as an important content for their students. To promote teachers' ability to adopt problem-solving approaches in their teaching, the delivery of pre-service and in-service teachers' education programs should focus on a contextualized delivery and problem-solving approach. These programs should emphasize the importance of context and authentic activities in equipping teachers with the necessary skills and knowledge to teach LS (Fox-Turnbull and Snape, 2011). Emphases should also be placed on practical activities consistent with the practical nature of LS and in line with the recent educational 
reform efforts in Oman that focus on learning by doing (Rassekh, 2004).

The use of ICT in implementing LS activities cannot be fully effective unless teachers re ceive adequate training and support. Their skills and competencies relevant to ICT should be continuously updated to keep current with the most recent innovations in this area so they can transfer these competencies to students. To achieve this, pre and in-service teacher training institutions should undertake a more active role with regard to teacher training that goes beyond the development of basic ICT literacy skills to educationally-oriented training on ICT (A buhmaid, 2011). This entails that teacher educators and trainers should model the appropriate use of ICT in the delivery of the curriculum of teacher education and training programs inasmuch as LS teachers are re quired to incorporateICT into their own teaching of LS at schools (Mc Cormick, 2004).

To keep teachers informed regarding various innovations relative to LS, Omani universities and MoE should encourage LS specialists and researchers to publish more articles about LS in journals and magazines at both local and international levels. They should also provide more training specifically for administrators to familiarize them with the importance of LS. Pre-service programs should strengthen their emphasis on the LS knowledge and skills of pre-service teachers by offering more undergraduate courses relevant to $L S$.

In the Sultanate of Oman, as in many other countries, practical provisions similar to LS continue to struggle with inappropriate popular images of what they are. Policy makers, school boards, parents, and the society at large still tend to think of LS as a school subject in which students learn to make simple artifacts by processing materials with a variety of hand tools and simple machines. These prejudices need to be corrected. One way to do that can be through conducting awareness workshops to familiarize all concerned parties with the importance of and the need for such vital provision.

Due to lack of previous studies related to LS, the instrument used in this study could be adopted for use in other similar studies in the Sultanate of Oman and other countries in the Arab world. Quantitative and qualitative re search approaches should be carried out to gain a deeper insight into teachers' training needs related to the implementation of LS at the first and second cycles of the basic stage of schooling in the Sultanate of Oman.

\section{REFEREN CES}

Abuhmaid, A. (2011). ICT Training Courses for Teacher Professional Development in Jordan. TOJET: The Turkish O nline Journal of Educational Technology. 10(4), 195-210.

AI-N ofli, M. (2010). Perceptions of Social Studies Teachers about Social Studies Goals and Content Areas in Oman. European Journal of Educational Studies, 2(2), 175-186.

Al-Sa'aideh, Mon'im A. (2008). Actions Proposed by Teachers to Improve the Delivery of Pre-Vocational Education in Jordan. Journal of Instructional Psychology, 35(4), 317335.

Al-Saydeh, M. (2002). Pre-vocational education in Jordan: Implications for teacher education and in-service preparation. Unpublished Ph.D. Thesis, University of Huddersfield, England.

Benson, C. and Lunt, J. (2011). We're Creative on a Friday Afternoon: Investigating Children's Perceptions of their Experience of Design \& Technology in Relation to Creativity. Science Education Technology, 20(5), 679-687.

Cohen, L., Manion, L., and Morrison, K. (2000). Research M ethods in Education. Routledge, London, England.

Davies, T. (2000). Confidence! Its role in the creativity teaching and learning of design and technology. Journal of Technology Education, 12(1), 18-31.

Davis, E. (2004). Knowledge integration in science teaching: Analysing teachers' knowledge development. Research in Science Education, 34(1), 21-53.

Foster, P. (1997). Benefits of elementary-school technology education to children. Unpublished Doctoral Dissertation, University of Missouri, Colombia.

Foster, P. and Kirkwood, J. (1994). Fog catcher: Kids don't care if it's low tech. T.I.E.S., 6 (3), 16-20.

Foster, P. and Wright, M. (1996). Selected leaders' opinions of approaches to technology education. Journal of Technology Education, 7(2), 12-26. 
Fox-Turnbull, W. (2010). The role of conversation in design and technology. D es Technol Edu: Int J 15(1), 24-30

Fox-Turnbull, W. (2006). The inuences of teacher knowledge and authentic formative assessment on student learning in technology education. International Journal of Technology and D esign Education, 16(1): 53-77.

Fox-Turnbull, W. and Snape, P. (2011). Technology teacher education through a constructivist approach. D esign and Technology Education: An International Journal. 16(2), 4556.

Gerbracht, C., and Babcock, R. J. (1959). Industrial Arts for Grades K-6. Milwaukee, WI: Bruce.

Gerbracht, C., and Babcock, R. J. (1969). Ele mentary School Industrial Arts. New York: Bruce.

Gibson, K. (2007). Technology and Design at Key Stage 3: Perceptions of challenge. De sign and Technology Education: An International Journal, 12(1), 55-64.

Gibson, S. (2002). "Incorporating computerbased learning into pre-service education courses". Contemporary Issues in Technology and Teacher education [O nline serial]. Retrieved March12, 2003 from the World Wide Web: http:/ / www.citejournal.org/ vol2/ iss1/ cur rentpractice/ article2.cfm

Hendrix, M. (1986). Prevocational education implementation manual. Texas Education Agency, Austin, USA.

Issan, S. and Gomaa, N. (2010). Post Basic Education Reforms in O man: A Case Study. Literacy Information and Computer Education Journal (LICEJ), 1(1), 19-27.

Jones, A., M oreland, J. (2004). Enhancing Practicing Primary School Teachers' Pedagogical Content Knowledge in Technology. International Journal of Technology and Design Education, V ol. 14(2): 121-140.

Kirkwood, J. (2000). The status of technology education in elementary schools as reported by be ginning teachers. Journal of Industrial Teacher Education, 37(3). Retrieved on September 26, 2003 from the World Wide W eb: http://scholar.lib.vt.edu/ejournals /JITE/v37n3/kirkwood.html
Kirkwood, J. J., and Foster, P. F. (1999). Relating technology education to trends in elementary education. The Technology Teacher, 59 (3), 7-12.

Kozulin, A. (1998). Psychological Tools: A sociocultural approach to education. Cambridge, MA: Harvard University Press.

Lynch, R. (2000). High school career and technical education for the first decade of the $21^{\text {st }}$ century. Journal of $\mathrm{V}$ ocational Education Research, 25(2). Retrieved on march 26, 2004 from the World Wide Web: http:/ / scholar.lib.vt.edu/ ejournals/ JVER/ v25n2/ lynch.html

Masri, M. (1993). Pre-vocational education. In Masri (Ed) Introduction to Education. Amman, Jordan: Dar Al-Shorouq.

Mc Cormick, R. (2004). Collaboration the Challenge of ICT. International Journal of Technology and D esign Education, 14(2): 159-176.

McRobbie, C., Ginns, I., \& Stein, S. (2000). Pre service primary teachers' thinking about technology and technology education. International Journal of Technology and Design Education, 10(1), 81-101.

Ministry of Education (2012). Curriculum D ocuments for Life Skills Curriculum. General Directorate of Curriculum and Education Technology, MoE, Muscat, Oman.

Ministry of Education. (2001). Basic education in the Sultanate of Oman: The theoretical frame work. Muscat, Oman: Author.

Ministry of Education. (2006). From access to success: Education for all [EFA ]in the Sultanate of O man 1970-2005. Muscat, Oman: Author.

Ministry of Education. (2011). Educational statistics yearbook: 2010/2011. Muscat, Oman: Author.

Minton, B. and Minton, G. (1987). Teaching Technology to Children. Worcester, MA: Davis.

Muller, D. (1986). M easuring Social A ttitudes: A handbook for social researcher and practitioners. New York: Teachers College Press.

Özden, M. (2007). Problems with Science and Technology Education in Turkey. Eurasia Journal of M athematics, Science \& Technology Education, 2007, 3(2), 157-161.

Rassekh, S. (2004). Education as A M otor for De velopment: Recent education reforms in 0 man 
with particular reference to the status of women and girls. UNESCO: IBE, Geneva, Switzerland.

Reid, M. (2000) Towards Effective Technology Education in New Zealand. Journal of Technology Education, 11(2): 33-47.

Resta, P., Allen, N., Anderson, J., Davis, N., Muranov, A., Thomas, L., \& Uvarov, A., (2002) Information and Communication Technologies in Teacher Education: A Planning Guide. UNESCO Publications.

Rohaan, E. J., Taconis, R., \& Jochems, W. M. G. (2009). Measuring teachers' pedagogical content knowledge in primary technology education. Research in Science and Technological Education, 27(3), 327-338.

Rohaan, E. J., Taconis, R., \& Jochems, W. M. G. (2010). Reviewing the relations between teachers' knowledge and pupils' attitude in the field of primary technology education. International Journal of Technology and D esign Education, 20(1), 15-26.

Safari, M. (2011). Importance of Using Information and Communication Technologies (ICT) in Education. Journal of American Science. 7(6), 381-385.

Saud, M.; Shuaibu, B.; Tahir, L.; Buntat, Y.; Yahaya, N.; and Gital, A. (2011). A pplicability of information and communication technologies (ICTs) in the administration of technical and vocational education and training (TVET) in a knowledge-based society. International Journal of the Physical Sciences. 6(28), 6513-6520.

Stables, K. (1997). Critical issues to consider when introducing technology education into the curriculum of young learners. Journal of Technology Education, 8(2), 50-65.

Stein, S., McRobbie, C., and Ginns, I. (2002). Implications of missed opportunities for learning and assessment in design and technology education. Teaching and Teacher Education, 18(1):35-49.

Tweisat, A. (1998). The Effectiveness and Efficiency of Jordanian Prevocational Education Provision. Unpublished Ph.D Thesis, University of Huddersfield, England.

Twyford, J., \& Järvinen, E. M. (2000). The formation of children's technology concepts: A study of what it means to do tech- nology from a child's perspective Journal of Technology Education, 12(1), 32-48.

Ulaimat, M. (1991). Prevocational Education Teaching M ethodologies. Dar AI-Malahi, Irbid, Jordan. (in A rabic).

UNESCO (1974). Revised Recommendations Concerning Technical and Vocational Education. General Conference of UNESCO. The $18^{\text {th }}$ Session, Paris.

UNESCO (2002). Technical and Vocational Education and Training for the Twenty-first Century: UNESCO and ILO Recommendations, UNESCO Publications.

Volk, K. (1996). Industrial Arts Revisited: An Examination of the Subject's Continued Strength, Relevance and Value Journal of Technology Education 8(1), 27-39.

Volk, K. (2011). Technology Education is more than just Computers: A Paper from the second Annual Symposium of the Gulf Comparative Education Society. March 1617 (46-53). The Dubai School of Government, UAE.

Volk, K., Yip, W., \& Lo, T. (2003). Hong Kong pupils' attitudes toward technology: The impact of design and technology programs. J ournal of Technology Education, 15(1), 48-63.

Weber, K., \& Custer, R. (2005). Gender-based preferences toward technology education content, activities, and instructional me thods. Journal of Technology Education, 16(2), 55-71.

White, C. (1995). The place for technology in a constructivist teacher education program. Technology and Teacher Education Annual (pp. 290-293) Charlottesville, VA: Association for the Advancement of Computing in Education.

Williams, P. (2000). Design: The only methodology of technology? Journal of Technology Education, 11 (2), 48-60.

Wilson, V. and Harris, M. (2003). Designing the best: A review of effective teaching and learning of design and technology. International Journal of Technology and D esign Education, 13(3), 223-241. 